Acta Technologica Agriculturae 2

Nitra, Slovaca Universitas Agriculturae Nitriae, 2016, pp. 52-56

\title{
USING 3 × 3 MATRIX TO EVALUATE THE MANUFACTURING TECHNOLOGY IN FOOD COMPANY
}

\author{
Manuela INGALDI*1, Martin KOTUS², Katarína Lestyánszka ŠKŮRKOVÁ3 \\ ${ }^{1}$ Institute of Production Engineering, Czestochowa University of Technology, Czestochowa, Poland \\ ${ }^{2}$ Slovak University of Agriculture in Nitra, Slovak Republic \\ ${ }^{3}$ Institute of Industrial Engineering and Management in Trnava, Slovak University of Technology in Bratislava, \\ Slovak Republic
}

\begin{abstract}
In order to produce goods of sufficient quality finding buyers in the market, a company must have an adequate knowledge of their production technology. Technologies and finished products at the same time will affect the position of the company in the market and hence its existence in this market. Therefore, it is so important for every company to determine the appropriate technological strategy. The $3 \times 3$ matrix is a very useful tool to do so. This matrix shows the relation between technological possibilities of the company and its position in the market. However, that requires changing the scale used in the matrix. In practice, this means that both those that have a positive impact on the company and those that have a negative impact on it can be included in the factors. The research was conducted in a food industry company. It turned out that the research company was located in field of the matrix marked as,Improve marketing.' It means that the company should put more emphasis on improving the factors related to its position in the market.
\end{abstract}

Keywords: manufacturing process; technology; strategy; food company; technological possibilities; position in the market

Technology can be defined as the overall knowledge of a particular method of producing some good or achieving a specific industrial or service effect. From this definition it results that the company in order to produce products of sufficient quality, which find buyers in the market, must have an adequate knowledge of their production (Mura, 2012; Ťavodová, 2008).

Many products require the use, or can be produced with different technologies, but their choice depends on many factors such as technical, economic, social or cultural, e.g. cost, time, legislation, safety, convenience, etc. Production equipment owned by the company affect the technology and quality of products and the final result of production at the same time (Ulewicz, 2003; Selejdak, 2003)

Especially companies of the food industry must use the proper equipment, and employees must have sufficient knowledge and skills. Therefore, it is important to meet all requirements in this case. This means that the company must have an appropriate technology. Machine equipment in the food industry has to meet strict hygienic standards (Ingaldi and Lestyánszka Škůrková, 2014). Whereas this equipment is also a subject of degradation processes such as abrasion and corrosion, it is necessary not only to choose an appropriate technical material but also anticorrosion protection. There are two types of anticorrosion coatings: inorganic and organic. In the food industry, mostly zinc coatings and ecologic waterborne paint systems are used (Votava, 2013a; Votava, 2013b).

Every company, also from the food industry, must plan its activities in short and long term. The long-term planning means to determine an appropriate strategy. The strategy is a set of criteria and decision rules that shape the functioning and development of the organization in a changing environment. This allows the management of the company to know in which business to get involved, how to use the possibilities of creative cooperation (synergy) between different units, and how to distribute resources among them (Knop and Borkowski, 2011; Mura, 2011; Ťavodová, 2006).

Every company depends on the development of new technologies. Before a new technology is introduced into production, many tests have to be processed. The current trend is to join heterogeneous material by a CMT (Cold Metal Transfer) method. This method is also appropriate for the food industry (Balara, 2013; Matisková, 2013).

The own technologies and finished products at the same time will affect the position of the company in the market and hence its existence in this market. Therefore, it is so important for every company to determine the appropriate technological strategy (Dziuba et al., 2011; Kardas and Prusak, 2013).

The main goal of the article was to evaluate the production process of meat products in the chosen company. For this purpose, the $3 \times 3$ matrix was used. Technological possibilities of the company and its position in the market are taken into account in the matrix. There was proposed a change related to the interpretation of the scale used in the matrix, which allowed taking into account both factors with the positive as well as negative influence. The determination of position will allow identifying future 
directions of the research company and can be used by its managers to take production decisions.

Nevertheless, this is the first stage of the study on evaluation of the manufacturing technology in the chosen company. Subsequently, the authors also plan to use other methods that enable evaluating other elements connected with the technology owned by the company. These studies as a whole will help the company managers to take decisions on the technology used in the company.

\section{Material and methods}

The first stage of research was to determine the factors that would describe the functioning of business. All of these factors were divided into two groups: those that determine the technological possibilities of the company and those that determine its position in the market. All of these factors were evaluated in a scale from 1 to 9 , where 1 indicates a negative impact, 5 is a neutral or very small impact, but there is a factor, while 9 indicates a positive impact. Then, an average value of both groups of factors was calculated. These averages helped to define the technological position of the company in the $3 \times 3$ matrix.

The $3 \times 3$ matrix described by Borkowski and Ingaldi (2013) and Ingaldi and Borkowski (2013), which consists of 9 fields defining the technological position of the company, was used for analysis. However, the scale used in the matrix was changed. Until now, evaluation 1-3 means weak impact, 4-6 average, and 7-9 strong impact (Lowe, 1999). But due to the presence of negative factors that change the technological position of the company, the previously described evaluation was used. It was also assumed that the borders of individual fields inside the matrix take value 0.5 . The $3 \times 3$ matrix is presented in Figure 1.

The research was conducted at Production Trade Service Company, which was established in 1998 and is located in southern Poland. All economic activities are conducted in leased facilities. Continual expansion and modernization related to the necessity of expansion and modernization of production facilities have been taking part practically from the beginning of the company, which determines the development of the company. With the increase in production capacity, the quality and assortment of products in the company has improved.

The building of the company is a complex of buildings with a total usable area $150 \mathrm{~m}^{2}$, including:

- warehouse of slaughter animals;

- slaughterhouse;

- social room of the slaughterhouse;

- animal partition room;

- social room of the animal partition room;

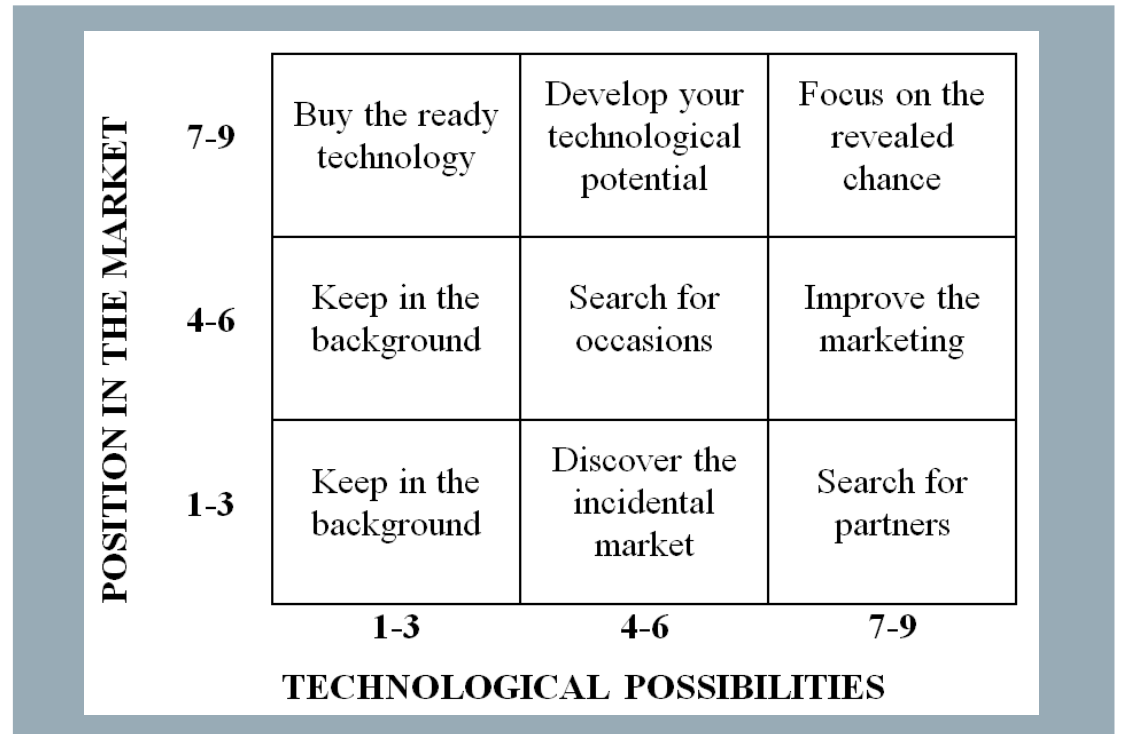

Figure 1
Scheme of the $3 \times 3$ matrix

Source: Borkowski and Ingaldi, 2013
- production hall;

- warehouse of final products.

The modernization of production facilities was connected with the process of adaptation to EU standards. During the expansion, a lot of machines and equipment necessary for slaughter, partition and processing were bought.

Production Trade Service Company is adapted to operate in single market conditions and it meets the requirements set by the European Union for the processing facility. It has regulated situation regarding the use of the environment and remains under constant veterinary supervision. In 2000, it has implemented the HACCP (hazard analysis and critical control point) system.

The company conducts production activities and it generated almost 100 $\%$ of the profit from it. It carries a full range of production activities in the area of:

- slaughter of swine;

- partition of beef and pork;

- meat processing.

The group of products offered by the company includes: cured meats, smoked products, haslets, pork sides, pork and beef. Taking into account the tastes of customers, verified and the best Polish recipes and carefully selected spices, which allows keeping the characteristic flavour and highquality cured meats, are used during the production of cured meats.

\section{Results and discussion}

In Table 1 and Table 2, the factors connected with technological possibilities of the company and deciding about its position in the market are presented. It also gives the evaluation of each factor and average evaluation for both groups. According to both averages, the relation between technological possibilities and its position in the market were determined. This relation is shown in Figure 2.

It results from the relation between technological possibilities of the research company and its position in the market that the company is located in the field of $3 \times 3$ matrix defined as 'Improve the marketing'. The average evaluation of technological 
Table 1 Classification of the $3 \times 3$ matrix factors connected with technological possibilities of the company

\begin{tabular}{|l||r|l|}
\hline \multicolumn{3}{|c|}{ Technological possibilities } \\
\hline $\mathbf{1}$ & Level of production machines & 7 \\
\hline $\mathbf{2}$ & Means of transport & 7 \\
\hline $\mathbf{3}$ & Changeover time & 6 \\
\hline $\mathbf{4}$ & Synchronization between operations & 8 \\
\hline $\mathbf{5}$ & Staff experience & 8 \\
\hline $\mathbf{6}$ & Company experience & 8 \\
\hline $\mathbf{7}$ & Pepeatability of flavour & 8 \\
\hline $\mathbf{8}$ & Possibility of new products & 9 \\
\hline $\mathbf{9}$ & Funds for investment & 6 \\
\hline $\mathbf{1 0}$ & EU funding & 7 \\
\hline $\mathbf{1 1}$ & Suppliers of raw materials & 5 \\
\hline $\mathbf{1 2}$ & Storage space & 7 \\
\hline $\mathbf{1 3}$ & 6.9 & \\
\hline Average & Source: own study & \\
\hline
\end{tabular}

possibilities of the research company was 6.9. As described in the methodology of research, the borders of individual fields inside the matrix take value 0.5 , so this evaluation may be included in range $7-9$. The average of position in the market was 5.3 , so it directly determines the field in range 4-6. Such a position means that the company should put more emphasis on improving the factors related to its position in the market.

However, it should be noted that due to the fact that technological possibilities have been evaluated in average at 6.9 (which is almost at the border of fields), the authors decided to take this fact into account in the discussion as well, because this may indicate the trend for companies to move to the field of the matrix defined as 'Search for occasions'. We can say that for both groups of factors the research company is among average companies. Therefore, according to the authors, the company should look for opportunities to improve both groups of factors.

Some factors had positive influence on the results. 'Repeatability of flavour' should be mentioned among the factors connected with technological possibilities of the research company. The company has developed some standards for products. It prepared appropriate procedures associated with the manufacturing process, which allow maintaining of certain flavours of individual products. This is very important because in this way the customer knows what he buys and what to expect at home at the time of eating. He is used to the flavour, he likes it and so he comes back for the product. These procedures also enable the synchronization between operations, so it is easier for an accurate planning of the production process.

An important factor deciding about technological possibilities of the research company is also 'Company experience', especially the fact that the company appeared 15 years ago in the market, which made it possible to meet
Table 2 Classification of the $3 \times 3$ matrix factors deciding about the position of the company in the market

\begin{tabular}{|l||c|l|}
\hline \multicolumn{3}{|c|}{ Position in market } \\
\hline $\mathbf{1}$ & Tradition & 9 \\
\hline $\mathbf{2}$ & Image of the company & 7 \\
\hline $\mathbf{3}$ & Assortment flexibility & 7 \\
\hline $\mathbf{4}$ & Level of marketing & 4 \\
\hline $\mathbf{5}$ & HACCP system & 7 \\
\hline $\mathbf{6}$ & Regular customers & 8 \\
\hline $\mathbf{7}$ & Demand for meat & 8 \\
\hline $\mathbf{8}$ & New markets & 6 \\
\hline $\mathbf{9}$ & the local market & 6 \\
\hline $\mathbf{1 0}$ & Competition & 3 \\
\hline $\mathbf{1 1}$ & Offers from foreign companies & 4 \\
\hline $\mathbf{1 2}$ & Economic crisis & 4 \\
\hline $\mathbf{1 3}$ & Cost of labour & 3 \\
\hline $\mathbf{1 4}$ & Course of PLN (Polish zloty) & 4 \\
\hline $\mathbf{1 5}$ & Prices & 7 \\
\hline $\mathbf{1 6}$ & Highway tolls & 4 \\
\hline $\mathbf{1 7}$ & Unemployment & 3 \\
\hline $\mathbf{1 8}$ & Rource: own study & \\
\hline $\mathbf{A v e r a g e}$ & & \\
\hline & & \\
\hline
\end{tabular}

the preferences of customers, adapt to market requirements. 'Staff experience' is also important. The company's policy is to maintain the current crew. This is important from the point of view of management and cost of labour. Another reason is that the company employing the worker not only invests in his training and education but first of all reveals its recipes to prepare different types of meats. Quitting the work of such an employee and going especially to the competition is a great loss for the company.

All these factors have an influence on another factor that was highly evaluated - 'Product quality'. It is responsible primarily for the fact that thanks to its technology the company is able to meet the demands of customers.

Among the factors that determine technological possibilities of the research company, 'Possibility of new products' deserves special attention. This factor was the lowest evaluated and can be considered as a factor that lowers the average evaluation of this group factors. The company has a wide range of meat products and charcuterie, but the possibility of introducing something new to production is limited.

Among the factors that determine the position of the company in the market, 'Tradition' of the company deserves special attention. For customers the word 'tradition' is very important. After more than 15 years, the company has become recognized in the market. Customers who are familiar with its products want to purchase them. So 'Regular customers' are the most important factor in the company's 


\begin{tabular}{|c|c|c|c|c|}
\hline \multirow{3}{*}{ 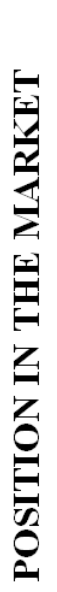 } & $7-9$ & $\begin{array}{c}\text { Buy the ready } \\
\text { technology }\end{array}$ & $\begin{array}{c}\text { Develop your } \\
\text { technological } \\
\text { potential }\end{array}$ & $\begin{array}{c}\text { Focus on the } \\
\text { revealed } \\
\text { chance }\end{array}$ \\
\hline & 4-6 & $\begin{array}{l}\text { Keep in the } \\
\text { background }\end{array}$ & $\begin{array}{l}\text { Search for } \\
\text { occasions }\end{array}$ & $\begin{array}{l}\text { Improve the } \\
\text { marketing }\end{array}$ \\
\hline & 1-3 & $\begin{array}{l}\text { Keep in the } \\
\text { background }\end{array}$ & $\begin{array}{c}\text { Discover the } \\
\text { incidental } \\
\text { market }\end{array}$ & $\begin{array}{l}\text { Search for } \\
\text { partners }\end{array}$ \\
\hline & & 1-3 & $4-6$ & $7-9$ \\
\hline
\end{tabular}

\section{TECHNOLOGICAL POSSIBILITIES}

Figure 2

Position of the research company in the $3 \times 3$ matrix Source: own study

position in the market. Therefore, that factor was highly evaluated.

High 'Demand for meat' is the next important factor connected with the company's position in the market. The majority of human population are people for whom a compulsory element of the diet is meat. Meat is a food product providing a variety of nutrients and particularly proteins containing all the amino acids, vitamins of group B, especially ones that are not present in plant food, vitamin B12, vitamin A and D, minerals containing micronutrients, saturated and unsaturated fats, enzymes, etc. Therefore, the demand for meat will always be high.

'Restrictive legislation' has a negative impact on the average evaluation of the company's position in the market. The company must keep up with all legislation related to the production of meat products and their changes. Unfortunately, it has no influence on this factor and it cannot do anything to improve the evaluation of this factor either.

A similar situation can be observed in case of the factor 'Unemployment'. Unfortunately, this factor has an influence partly on the demand for meat products. It is true, as noted earlier, that the demand for meat is high due to the human diet and nutritional values of meat. However, in social groups where unemployment is really high, people often reduce its consumption in favour of cheaper products, such as potatoes or grits.

'Cost of labour' has a high negative impact on the position of the company in the market. Its level impacts high prices of products. In order not to raise too much labour cost, it is important, as mentioned earlier, to maintain the staff. New employees must be thoroughly trained, they must acquire experience, which unfortunately is associated with an increase in such costs.

The next factor with negative influence on the position of the company is 'Competition'. The company can search for improvement in this area. In the free market economy, it is easy to open own business, also the company of meat industry, but it is not so easy to stay in the market. The researched company already has a certain tradition, which has been very highly evaluated, it has some experience, a good image in the market. However, there are many similar companies, large and small, that can be a big threat for the researched company in the future. Especially, if there is a group of customers who like to experiment with products and who may decide to purchase the products from these companies.

However, it should be noted that many of the factors that influenced the company's position in the market are external factors. For that reason, the company cannot do anything to change evaluations of these factors increase. Therefore, it should deal with these factors that were evaluated quite high.

The company should begin to improve its position in the market from marketing campaigns. In the food/meat industry, it is difficult. The company may look for opportunities to acquire funds from the EU or Regional Development Agency. There are many support programmes for small and medium-sized agri-food companies that the company could use. Some of these programmes precisely help to improve the marketing strategy. It would also enable building a positive image, and the company would become recognizable in other market.

It would be also helpful in searching for new markets in which the company could expand its activities.

Concerning the elements connected with technological possibilities, it is important to improve 'Suppliers of raw materials'. The company should think about new suppliers in case of problems or introduce a procedure regarding orders of raw materials.

\section{Conclusion}

The company of the food industry, including the meat industry, operates in the same environment as other companies. The technology used by this company determines the quality of finished products and hence customer satisfaction. Its position in the market depends on the competitiveness of products. Therefore, it is important to choose an appropriate strategy that will decide about its further development.

The purpose of the article was to evaluate the technological position of the company producing meat products with use of the $3 \times 3$ matrix. Two groups of factors, i.e. technological possibilities and the company's position in the market, were taken into account in the matrix.

An important point of the article was to propose a new interpretation of the scale in relation to that given so far in literature. Until now, evaluation 1-3 means weak impact, 4-6 average, and 7-9 strong impact. It was proposed that 1 means negative impact, 
5 neutral, but there is a factor, while evaluation 9 means strong impact. This allowed two groups of factors, those which have a positive impact on the company and those with a negative impact as well, to be taken into account.

Among the factors of the group connected with technological possibilities of the researched company, the following factors have the largest positive impact: 'Repeatability of flavour', 'Staff experience' and 'Company experience', 'Synchronization between operations' and 'Product quality', while among the factors of the group connected with its position in the market, there are: 'Tradition', 'Regular customers' and 'Demand for meat'. It turned out that the researched company is placed in the field of the $3 \times 3$ matrix defined as 'Improve marketing'. This means that the company should put more emphasis on improving the factors related to its position in the market.

In the article, it is shown that a simple tool, which is the matrix of relation between technological possibilities and the company's position in the market, also called the $3 \times 3$ matrix, can be used in meat industry companies without any problems for its evaluation and to determine the elements of its strategy.

\section{References}

BALARA, M. 2013. The upgrade methods of the pneumatic actuator operation ability. In Applied Mechanics and Materials, vol. 308, 2013, pp.63-68.

BORKOWSKI, S. - INGALDI, M. 2013. Workers evaluations of ribbed wire competition and rolling mill technological possibilities. In $22^{\text {nd }}$ International Conference on Metallurgy and Materials 'METAL 2013', TANGER, Czech Republic, Ostrava, 2013. pp.1920-1925.

DZIUBA, S. T. - SZOLTYSEK, K. - KOZYRA, C. 2011. Application of FAM - Fail Assessment Method - to optimization of unit costs of producing flours for special purposes. In: Borkowski, S. - Krynke, M. (Eds). Improvement of Production Process. Trnava :TRIPSOFT, 2011. pp. 28-39.

INGALDI, M. - BORKOWSKI, S. 2013. Management of the technical possibilities and product competition in the market in the chosen company. In Nauka i obrazovanie transportu. Materialy V Mezdunarodnoj naucno-prakticeskoj konferencii, posvascennoj 40-letiu Samarskogo gosudarstvennogo universiteta putej soobscenia, SamGUPS, Samara, 2013. pp. 104-107.
INGALDI, M. - LESTYÁNSZKA ŠKŮRKOVÁ, K. 2014. Company strategy determination in food company using SWOT method. In Acta Technologica Agriculturae, vol. 17, 2014, no. 3, pp.66-69.

INGALDI, M. - LESTYÁNSZKA ŠKU゚RKOVÁ, K. 2014. Technological level of machines in production process of screws. In Acta Technologica Agriculturae, vol. 17, 2014, no. 4, pp.101-104.

KARDAS, E. - PRUSAK, R. 2013. Analysis of the utilization of machinery and equipment from the point of view of their productivity and effectiveness in a printing enterprise. In $5^{\text {th }}$ International Scientific Conference 'Management of Technology. Step to Sustainable Production' MOTSP. Zagreb : Croatian Association for PLM, 2013.

KNOP, K. - BORKOWSKI, S. 2011.Analysis of quality problems in food industry on example of the tomato concentrate. In Borkowski, S. - Konstanciak, M. (Eds). Determinants of Product Quality. Lviv : Liga-Press Lviv, 2011. pp. 66-81.

LOWE, P. 1999. Zarządzanie technologią. Możliwości poznawcze i szanse. $1^{\text {st }}$ ed. Katowice : Śląsk, 1999.

MATISKOVÁ, D. 2013. Strategické plánovanie - základ kvality riadenia podniku. In Kvalita, vol. 21, 2013, no. 1, pp.37-40.

MURA, L. 2011. Všeobecná ekonomická teória. Bratislava : CRR.SK, 2011.

MURA, L. 2012. Úvod do podnikania. Komárno : Univerzita J. Selyeho, 2012.

SELEJDAK, J. 2003. Influencing factors onto quality of welded pipes. In Metalurgija, vol. 42, 2003, no. 1, pp. 65-67.

T̃AVODOVÁ, M. 2006. Prehl'ad a možnosti použitia jednoduchých nástrojov riadenia kvality. In Trendy lesníckej, drevárskej a environmentálnej techniky a jej aplikácie vo výrobnom procese. Zvolen : Technická univerzita vo Zvolene, 2006. pp.129-135.

ŤAVODOVÁ, M. 2008. Model CAF ako nástroj komplexného manažérstva kvality. In Aktuálne manažérske trendy v teórii a praxi. Žilina : Žilinská univerzita, 2008. pp. 211-214.

VOTAVA, J. 2013a. Corrosion resistance of water-thinnable paint systems. In Journal of Central European Agriculture, vol. 14, 2013, no. 4, pp.1271-1278.

VOTAVA, J. 2013b. Corrosion resistance of zinc-based systems in $\mathrm{NaCl}$ environment. In Acta Universitatis Agriculturae et Silviculturae Mendelianae Brunensis, vol. 61, 2013, no. 5, pp. 1487-1495.

ULEWICZ, R. 2003. Quality control system in production of the castings from spheroid cast iron. In Metalurgija, vol. 42, 2003, no. 1, pp. 61-63. 